\title{
Carcinoma of the gallbladder
}

RICHARD C. SPINALE, DO

JACK F. MEEKER, DO

Primary gallbladder cancer has a reported incidence of $0.5 \%$, but appears to be increasing, resulting in 6,500 deaths annually. It nearly always is diagnosed at a late stage. Adenocarcinoma is the predominant cell type. The five-year survival rate is a dismal $1 \%$ to $12 \%$. Reported here are five cases identified over an 18-month period among 206 patients who underwent cholecystectomies.

Gallbladder carcinoma will cause approximately 6,500 deaths this year. ${ }^{1}$ The incidence of primary cancer of the gallbladder has been reported to be $0.5 \%$ in operations of the biliary tract. ${ }^{2}$ Despite being the most common malignancy of the biliary tract and the fifth most common gastrointestinal tract malignancy, the disease nearly always is diagnosed at a late stage. ${ }^{3}$ Preoperative diagnosis of gallbladder cancer is unlikely, and the finding of an early-stage lesion usually is happenstance. The overall mean age at diagnosis is 67 years. ${ }^{4}$ The female-to-male ratio is $3: 1 .^{2}$ The disease rarely occurs in the absence of biliary calculi. Adenocarcinoma is the predominant cell type; it accounts for $84 \%$ to $90 \%$ of all cases. ${ }^{2,5}$ The remaining $10 \%$ to $16 \%$ of cases involve adenosquamous, squamous, anaplastic, adenocanthomatous, sarcomatous, scirrhous, and even rhabdomyosarcomatous cell types. ${ }^{6}$

The five-year survival rate for patients with resected gallbladder adenocarcinoma is $1 \%$ to $12 \% .^{1-3,7}$

In this paper, we report an alarmingly high incidence of five cases of carcinomas of the gallbladder found at a community hospital during an 18month period. Also, recommendations regarding operative diagnosis and treatment are discussed.

\section{Materials and methods}

Tumor registry records of all patients with gallbladder cancer that was diagnosed at our institution during the past 18 months were reviewed. Abstracted data included patient age, sex, race, duration of symptoms, preoperative diagnosis, extent and type of disease, treatment, and length of survival. Length of survival data were based on the current known condition of the four patients available for follow-up. For this analysis, the one patient lost to follow-up five months after surgery was presumed dead.

Surgical procedures included cholecystectomy (four patients), drainage of a gallbladder abscess (one patient), exploration of the common bile duct (two patients), and omentectomy, partial liver bed resection, and removal of porta hepatis lymph nodes (one patient). No patient underwent radical surgical procedures (Whipple's operation, partial hepatectomy, or pancreaticoduodenectomy).

\section{Report of cases}

\section{Case 1}

An alert, 72-year-old woman was admitted for elective cholecystectomy. For one year, she had been experiencing right upper quadrant and midscapular pain. Ultrasonography confirmed cholelithiasis. Preoperative laboratory values, including liver enzyme levels, were normal, except for the hemoglobin level $(11.9 \mathrm{~g} / \mathrm{dL})$ and hematocrit value $(35.3 \%)$, which were indicative of anemia.

Operative findings included evidence of chronic cholecystitis and cholelithiasis. The findings of operative cholangiography were unremarkable. No malignancy was suspected, and the gallbladder was not opened and grossly inspected during surgery.

Microscopic pathology review revealed moderately differentiated adenocarcinoma of the gallbladder; it arose from a polypoid mass and extended deeply through the muscular wall to the subserosal soft tissues. Malignancy also was noted in perineural and vascular spaces. 

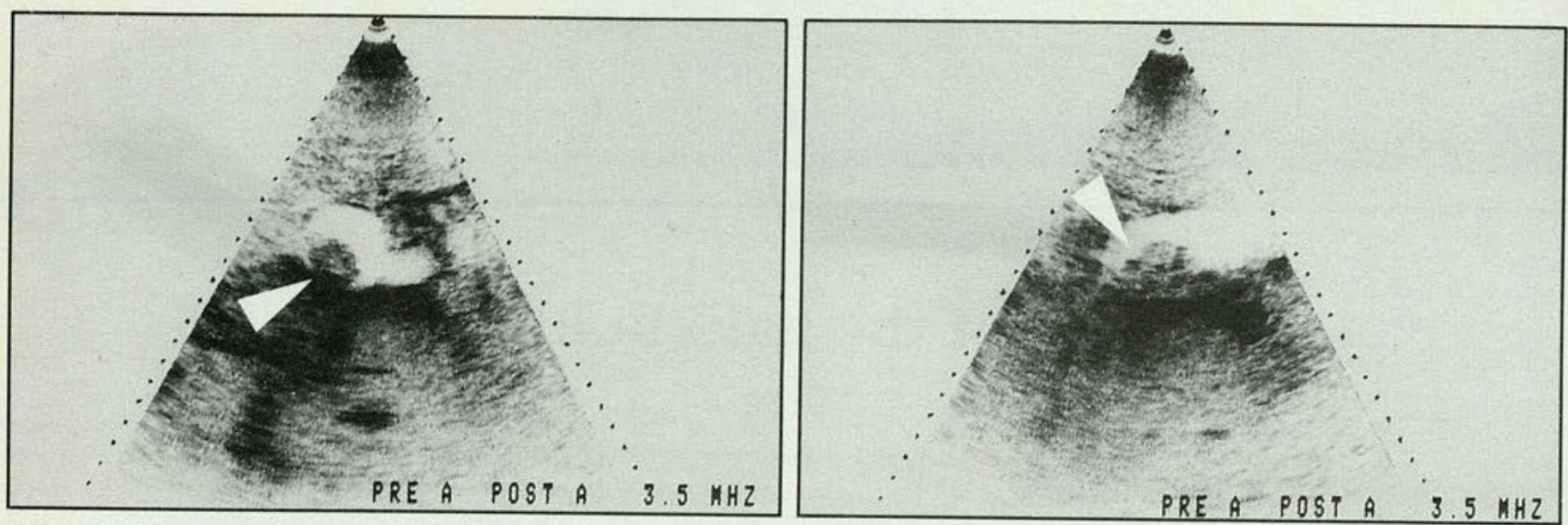

Figure 1. Ultrasonograms of gallbladder mass (arrows) reveal a solid tumor in the gallbladder neck (case 2).

The patient recovered without incident. Findings of a workup for metastatic disease were negative. She received radiation therapy to the liver bed. Three months postoperatively, she was discovered to have an incisional mass, which proved to be metastatic adenocarcinoma. She later suffered a dense cerebrovascular accident and subsequently died.

\section{Case 2}

A 55-year-old man with a history of severe peptic ulcer disease complained of incapacitating right upper quadrant and epigastric pain of two days' duration. He had undergone two previous operations, including a Billroth I procedure, for ulcer disease. On admission, the serum amylase level was $255 \mathrm{U} / \mathrm{L}$; this value eventually increased to $2,028 \mathrm{U} / \mathrm{L}$. The serum lipase value was elevated to $4.3 \mathrm{U} / \mathrm{L}$. The lactic dehydrogenase level was $221 \mathrm{U} / \mathrm{L}$, the SGOT value was $59 \mathrm{U} / \mathrm{L}$, and the SGPT level was $41 \mathrm{U} / \mathrm{L}$. The WBC count on admission was 5,100 / cu $\mathrm{mm}$, but within 24 hours, it had risen to $21,100 / \mathrm{cu}$ $\mathrm{mm}$. The other laboratory values were normal.

Abdominal roentgenography revealed an ileus. Ultrasonography revealed a distended, tortuous gallbladder, cholelithiasis, and a 2-cm solid mass within the gallbladder neck (Fig 1). Computed tomography (CT) showed a distended, bilobular gallbladder, cholelithiasis, and associated mass (Fig 2). The head of the pancreas was edematous.

The admitting diagnosis was gallstone pancreatitis, with recurrent peptic ulcer disease and gallbladder carcinoma to be ruled out. Esophagogastroduodenoscopy demonstrated only superficial erosions of the gastric remnant.

After five days of intravenous antibiotic therapy, the serum amylase level and WBC count returned to normal ranges, and cholecystectomy was performed. The gallbladder was bisected after removal and inspected. A polypoid mass specimen was obtained for frozen section analysis, which failed to prove malignancy. Operative cholangiography showed irregular filling of the distal common

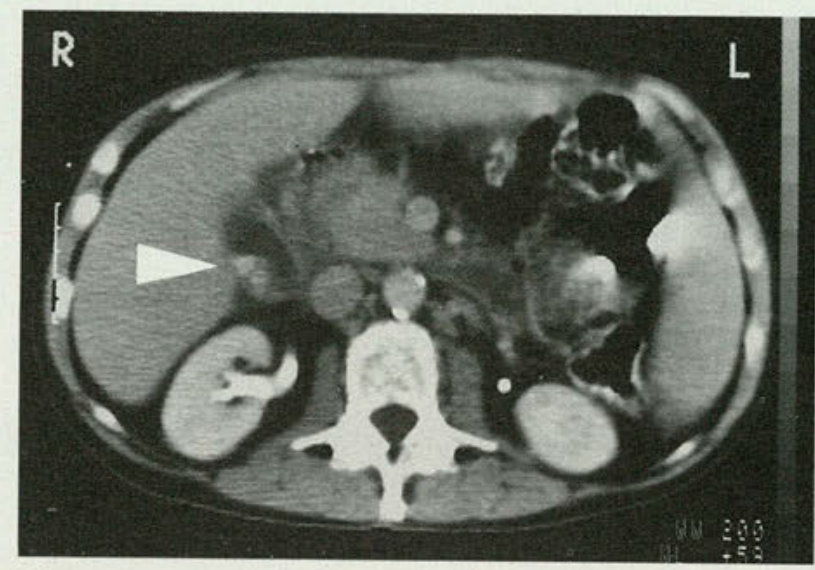

Figure 2. Computer tomographic scan of gallbladder mass shows tumor in a bilobed gallbladder (case 2).

bile duct and narrowing. Observations from common duct exploration, choledochoscopy, and T-tube cholangiography were normal.

The patient's recovery was uncomplicated. The Armed Forces Institute of Pathology findings were gallbladder adenoma and tubopapillary intramural adenocarcinoma. Twenty-five months postoperatively, there was no evidence of recurrence or metastatic disease.

\section{Case 3}

A 67-year-old woman with acute cholecystitis was admitted. She had been experiencing nausea, flatulence, bloating, fatty food dyscrasias, and right upper quadrant and right-sided scapular pain for three weeks.

Ultrasonography revealed cholelithiasis. Findings of an upper gastrointestinal series were noncontributory. CT scanning revealed metastatic liver disease. Laboratory values were as follows: total bilirubin, $5.4 \mathrm{mg} / \mathrm{dL}$; direct bilirubin, $4.4 \mathrm{mg} / \mathrm{dL}$; alkaline phosphatase, 926 U/L; SGOT, 262 U/L; and SGPT, 184 U/L. Serum amy- 
lase and serum lipase levels and initial complete blood cell count were within normal ranges.

At surgery, a gallbladder abscess, extensive malignancy, and liver metastasis were found. The abscess was drained. Microscopic study revealed moderately to poorly differentiated adenocarcinoma. The patient received palliative chemotherapy but survived only three months.

\section{Case 4}

A 62-year-old woman was admitted for urgent cholecystectomy. For six months, she had suffered postprandial eructations, fatty food intolerance, and nausea. Her stools were acholic. Cholelithiasis and choledocholithiasis had been documented by outpatient ultrasonography. Laboratory values were as follows: total bilirubin, $4.9 \mathrm{mg} / \mathrm{dL}$; alkaline phosphatase, $793 \mathrm{U} / \mathrm{L}$; SGOT, $72 \mathrm{U} / \mathrm{L}$; ESR, 45 $\mathrm{mm} / \mathrm{h}$; and urinary bilirubin, $4+$. The remaining laboratory values were within normal ranges.

At surgery, a dense mass was palpated in the gallbladder fundus; frozen section analysis revealed gallbladder adenocarcinoma. Cholecystectomy, omentectomy, partial liver bed resection, common bile duct exploration with T-tube choledochostomy, and removal of porta hepatis lymph nodes were performed.

The final pathology report confirmed moderately differentiated adenocarcinoma of the gallbladder, with metastasis to omentum. Findings of liver and bone scanning were normal. The patient's recovery was uncomplicated. Postoperatively, 5-fluorouracil therapy was administered. Five months after surgery, the patient was lost to follow-up.

\section{Case 5}

A 68-year-old woman was admitted with obstructive jaundice, which was thought to be secondary to choledocholithiasis. Epigastric and subcostal pain, food dyscrasias, occasional nausea and vomiting, steatorrhea, claycolored stools, dark urine, and jaundice had been present for four weeks.

Ultrasonography revealed cholelithiasis. The alkaline phosphatase level was $534 \mathrm{U} / \mathrm{L}$, the serum $\mu$-glutamic transpeptidase value was $119.2 \mathrm{U} / \mathrm{L}$, and the total bilirubin value was $8.4 \mathrm{mg} / \mathrm{dL}$. Urinanalysis showed a bilirubin value of $3+$. Remaining laboratory values were within normal ranges.

During surgery, cholelithiasis and an empyema were found, as was a mass thought to be carcinoma. Frozen section specimens were not found to be malignant, but final paraffin sections revealed well-differentiated adenocarcinoma of the gallbladder, with deep extension through the gallbladder wall into the liver bed.

Chemotherapy and local radiation therapy were recommended, but the patient refused further therapy and has been lost to follow-up.

\section{Results}

The clinicopathologic findings in this study are summarized in Table 1.
During an 18-month period (November 1985 to May 1987), 206 cholecystectomies were performed in our community hospital. Five of these patients were found to have carcinoma of the gallbladder, for an incidence of $2.4 \%$. The female-to-male ratio was $4: 1$. The patient's age at the time of diagnosis ranged from 55 to 72 years (average, 64.8 years). The duration of biliary symptoms ranged from two days to 12 months.

All five patients had cholelithiasis, and two also had choledocholithiasis. The signs and symptoms of chronic cholecystitis were present in three patients, while those of acute cholecystitis were present in two patients (one of whom had an abscess from a ruptured gallbladder). In only one patient with a CT- and ultrasonography-documented gallbladder mass was the diagnosis of carcinoma of the gallbladder suspected clinically. However, this tumor was thought to be benign on frozen section analysis at the time of surgery. Gallbladder carcinoma was not suspected in any of the other four patients.

On gross inspection, only one patient's tumor appeared obviously malignant. This patient also was noted to have omental metastasis (stage $\mathrm{V}$ carcinoma). Even the radiographically proved $2-\mathrm{cm}$ gallbladder mass in the patient in case 2 had the gross appearance of a benign polyp. Consultation with the Armed Forces Institute of Pathology confirmed that this lesion had a foci of intramucosal malignancy.

Cholecystecomy was performed in all but one patient, who had gallbladder perforation and a walledoff abscess. Two patients had common bile duct exploration for choledocholithiasis. One patient underwent omentectomy, partial liver bed resection, and removal of porta hepatis nodes.

Histologically, all malignancies were adenocarcinoma. A moderately differentiated grade of malignancy predominated.

Tumor staging was performed according to the Nevin classification system, ${ }^{8}$ which is delineated in Table 2. Two of the three patients who received chemotherapy had stage V disease; one died at three and the other at five months postoperatively. One patient received no adjuvant therapy and is alive and disease-free five months postoperatively. This patient had a stage I lesion. One patient with stage III disease received radiation therapy to her liver bed; the disease metastasized to the abdominal wall. She had a dense cerebrovascular accident three months after surgery. The fifth patient, who also had stage III disease, refused therapy and has been lost to follow-up. 
Table 1

Clinicopathologic Findings

\begin{tabular}{|c|c|c|c|c|c|c|c|c|c|c|c|c|c|}
\hline Case & Sex & $\begin{array}{l}\text { Age } \\
(\mathbf{y r})\end{array}$ & $\begin{array}{c}\text { Duration } \\
\text { of } \\
\text { symptoms }\end{array}$ & $\begin{array}{l}\text { Lithiasis } \\
\text { present }\end{array}$ & $\begin{array}{l}\text { Inflam- } \\
\text { mation } \\
\text { (type) }\end{array}$ & $\begin{array}{c}\text { Carcinoma } \\
\text { suspected } \\
\text { preopera- } \\
\text { tively }\end{array}$ & $\begin{array}{c}\text { Surgical } \\
\text { procedures }\end{array}$ & $\begin{array}{c}\text { Histo- } \\
\text { logic } \\
\text { findings }\end{array}$ & $\begin{array}{l}\text { Tumor } \\
\text { grade* }\end{array}$ & $\begin{array}{l}\text { Site of } \\
\text { metas- } \\
\text { tasis }\end{array}$ & Stage & $\begin{array}{l}\text { Adjuvant } \\
\text { therapy }\end{array}$ & $\begin{array}{l}\text { Survival } \\
\text { period }\end{array}$ \\
\hline 1 & $\mathrm{~F}$ & 72 & $12 \mathrm{mo}$ & Yes & Chronic & No & $\begin{array}{l}\text { Cholecys- } \\
\text { tectomy }\end{array}$ & $\begin{array}{c}\text { Adenocar- } \\
\text { cinoma }\end{array}$ & M & Liver bed & III & $\begin{array}{c}\text { Radia- } \\
\text { tion }\end{array}$ & $\begin{array}{c}\text { Alive at } \\
3 \mathrm{mo}\end{array}$ \\
\hline 2 & M & 55 & $2 \mathrm{~d}$ & Yes & Acute & Yes & $\begin{array}{l}\text { Cholecys- } \\
\text { tectomy } \\
\text { Common } \\
\text { bile duct } \\
\text { explora- } \\
\text { tion }\end{array}$ & $\begin{array}{l}\text { Adenocar- } \\
\text { cinoma }\end{array}$ & $\ldots$ & None & I & None & $\begin{array}{c}\text { Alive at } \\
5 \mathrm{mo}\end{array}$ \\
\hline 3 & $\mathrm{~F}$ & 67 & $3 \mathrm{wk}$ & Yes & Abscess & No & $\begin{array}{l}\text { Abscess } \\
\text { drainage } \\
\text { Biopsy }\end{array}$ & $\begin{array}{l}\text { Adenocar- } \\
\text { cinoma }\end{array}$ & M-P & Liver & V & $\begin{array}{l}\text { Chemo- } \\
\text { therapy }\end{array}$ & $\begin{array}{c}\text { Dead at } \\
3 \mathrm{mo}\end{array}$ \\
\hline 4 & F & 62 & $6 \mathrm{mo}$ & Yes & Chronic & No & $\begin{array}{l}\text { Cholecys- } \\
\text { tectomy } \\
\text { Common } \\
\text { bile duct } \\
\text { explora- } \\
\text { tion } \\
\text { Omentec- } \\
\text { tomy } \\
\text { Liver bed } \\
\text { resection }\end{array}$ & $\begin{array}{c}\text { Adenocar- } \\
\text { cinoma }\end{array}$ & M & Omentum & V & $\begin{array}{l}\text { Chemo- } \\
\text { therapy }\end{array}$ & $\begin{array}{c}\text { Dead at } \\
5 \mathrm{mo}\end{array}$ \\
\hline 5 & F & 68 & 4 wk & Yes & Chronic & No & $\begin{array}{l}\text { Cholecys- } \\
\text { tectomy } \\
\text { Cholangio- } \\
\text { graphy }\end{array}$ & $\begin{array}{l}\text { Adenocar- } \\
\text { cinoma }\end{array}$ & W & Liver bed & III & $\begin{array}{l}\text { Chemo- } \\
\text { therapy } \\
\text { Radia- } \\
\text { tion }\end{array}$ & $\begin{array}{c}\text { Alive at } \\
8 \mathrm{~d}\end{array}$ \\
\hline
\end{tabular}

\section{Discussion}

Primary carcinoma of the gallbladder continues to have an ominous prognosis. ${ }^{3}$ Only the rare patient with an in situ or stage I lesion potentially can undergo curative resection.

The disease occurs predominately in women who are in the seventh or eighth decade of life ${ }^{5}$ This malignancy, which not uncommonly occurs in women with Mexican and American Indian origins, is seen most frequently in the Southwest, an area that is endemic for biliary calculi. ${ }^{9}$

Usually, the disease is discovered incidentally at surgery in a patient suspected of having chronic cholecystitis secondary to cholelithiasis. The manifestations of the disease are vague and nonspecific. Gastric outlet obstruction, spontaneous gallbladder perforation, biliary duodenal fistula, gallstone ileus, and jaundice have been reported. ${ }^{1,4}$ Symptoms vary widely: Most common is pain, followed by nausea, vomiting, malaise, right upper quadrant mass, weight loss, back pain, abscess, and even concurrent adenocarcinoma of the ovary. ${ }^{3,5}$
Present diagnostic modalities are neither accurate nor sensitive in predicting gallbladder cancer. Ultrasonography is an unlikely tool for diagnosing an early tumor unless it is obstructing the gallbladder. ${ }^{5}$ Oral cholecystography, intravenous cholecystography, and endoscopic retrograde choledochopancreatography are all nonspecific for this tumor. ${ }^{3}$ Transhepatic cholangiography usually is helpful when the patient has disease that extends into the biliary tree. Computed tomography may show a mass or evidence of liver or portal metastasis. ${ }^{1,10}$

Rossman and associates ${ }^{10}$ have reported magnetic resonance findings of a marginated hypointense mass compatible with gallbladder carcinoma.

Isman and Bourgeon ${ }^{11}$ described three stages of gallbladder disease and recommended surgical procedures depending on the tumor stage at the time of diagnosis (Table 3).

These surgical procedures generally are viewed as radical, and survival has not been significantly improved. ${ }^{12}$ Most authors favor less radical proce- 
dures, as follows: simple cholecystectomy for Nevin's ${ }^{8}$ stage I; additional wedge resection of the liver and regional lymphadenectomy for stage II; extended right hepatic lobectomy and regional lymphadenectomy in low-risk patients with stages III and IV disease; and simple biopsy or palliative procedures for stage $\mathrm{V}$ tumors. ${ }^{3}$

Adjunctive therapy generally does not improve clinical status. Chemotherapy has not been shown to change the prognosis, but it may provide some palliative relief. ${ }^{3,13}$ The major objectives of radiotherapy are tumor mass reduction, pain relief, and relief of jaundice. ${ }^{3}$

The use of carcinoembryonic antigen and $\alpha$ fetoprotein assays as tumor markers has not been predictive, but Johnson and coworkers ${ }^{7}$ noted that patients whose tumor sections demonstrated a high histochemical content of acid mucopolysaccharides had a significantly better prognosis.

\section{Conclusions}

Carcinoma of the gallbladder is a rapidly progressive disease with an ominous prognosis and will remain so until early diagnosis becomes possible. The only proved predisposing epidemiologic factor is gallstones. Perhaps emphasis should be directed to the management of cholelithiasis.

We report the findings from five carcinomas of the gallbladder, which were found in 206 cholecystectomy specimens. This $2.4 \%$ incidence is considerably higher than the $0.5 \%$ incidence most authors report, and, therefore, the following procedures are recommended: (1) All gallbladder specimens should be opened and inspected in the operating room after removal, and frozen section analysis should be performed on any lesion suspected to be malignant; (2) surgical procedures for gallbladder cancer should be individualized according to the apparent clinical stage of the disease; (3) early cholecystectomy should be performed in patients with asymptomatic as well as symptomatic cholelithiasis; and (4) any preoperatively visualized gallbladder mass should be treated as carcinoma until proved otherwise.

\footnotetext{
1. Colletti PM, Ralls PW, Seigel ME, et al: Cholescintigraphy in gallbladder carcinoma. Clin Nucl Med 1986;11:270-273.

2. Dowling GP, Kelly JK: The histogenesis of adenocarcinoma of the gallbladder. Cancer 1986;58:1702-1708.

3. Roberts JW, Daugherty SF: Primary carcinoma of the gallbladder. Surg Clin North Am 1986;66:743-749.

4. Singer M, Chandar VP, Hookman P: Gallbladder carcinoma with gastric outlet obstruction and gallstone ileus. South Med $J$ 1986;79:902903.
}

Table 2

Nevin ${ }^{8}$ Staging Classification for Carcinoma of the Gallbladder

\section{Stage Extent of disease}

I Intramucosal

II Submucosa and muscularis involved

III All three layers involved

IV All three layers plus lymph nodes involved

V Direct extension or metastasis to liver or other organ

\begin{tabular}{|c|c|c|}
\hline \multicolumn{3}{|c|}{$\begin{array}{c}\text { Table } 3 \\
\text { Isman and Bourgeon's }{ }^{11} \text { Staging and Surgical } \\
\text { Procedures }\end{array}$} \\
\hline Stage & Extent of disease & $\begin{array}{l}\text { Recommended } \\
\text { procedures }\end{array}$ \\
\hline 0 & In situ & Simple cholecystectomy \\
\hline I & $\begin{array}{l}\text { Mucosa and muscu- } \\
\text { laris involved }\end{array}$ & $\begin{array}{l}\text { Cholecystectomy, median } \\
\text { subtotal hepatectomy, } \\
\text { and lymph node } \\
\text { dissection }\end{array}$ \\
\hline II & $\begin{array}{l}\text { Massive gallbladder } \\
\text { involvement and } \\
\text { extension to liver } \\
\text { and lymph nodes }\end{array}$ & $\begin{array}{l}\text { Right extended or total } \\
\text { median hepatectomy } \\
\text { and lymph node } \\
\text { dissection }\end{array}$ \\
\hline
\end{tabular}

5. Muir JIM, Morris DL: Carcinoma of the gallbladder. Br J Hosp Med 1986;36:278-280.

6. Inoshita S, Iwashita A, Enjoli M: Carcinosarcoma of the gallbladder: Report of a case and review of the literature. Acta Pathol Jpn 1986;36:913920.

7. Johnson LA, Lavin PT, Dayal YY, et al: Gallbladder adenocarcinoma: Prognostic significance of tumor acid mucopolysaccharide content. J Surg Oncol 1986;33:243-245.

8. Nevin JE: Carcinoma of the gallbladder-staging, treatment, and prognosis. Cancer 1976;37:141-148.

9. Whetstone MR, Saltzstein EC, Mercer LC: Demographic characteristics of gallbladder cancer in an area endemic for biliary calculi $\mathrm{Am} J$ Surg 1986;152:728-730.

10. Rossmann MD, Friedman AC, Radecki PD, et al: MR imaging of gallbladder carcinoma AJR 1987;148:143-144.

11. Isman H, Bourgeon R: A curative surgical approach to gallbladder carcinoma in its early stages Ital J Surg Sci 1986;16:117-122.

12. Evander A, Ihse I: Evaluation of intended radical surgery in carcinoma of the gallbladder. Br J Surg 1981;68:158-160.

13. Wright JC: Update in cancer chemotherapy: Gastrointestinal cancer, cancer of the small intestine, gallbladder, liver, and esophagus. $J$ Natl Med Assoc 1986;78:753-766.

From the Department of Surgery, Garden City Osteopathic Hospital, Garden City, Mich.

Reprint requests to Dr Spinale, 6255 N Inkster Rd, Garden Cityi, MI 48135. 